\title{
TARAWIH DAN TAHAJJUD (Tinjauan Persamaan Dan Perbedaan Dalam Pelaksanaan Dan Keutamaan)
}

\author{
Muhammad Mahmud Nasution \\ Lecturer of Syariah and Law Sciences Faculty at IAIN Padangsidimpuan. \\ Jl. T. Rijal Nurdin Km.4,5 Sihitang Padangsidimpuan 22733 \\ Email: mhdmahmudnst @gmail.com
}

\begin{abstract}
Tarawih prayer is prescribed only in the month of Ramadan. Outside of Ramadan, not prescribed tarawih prayers. Even though someone sunnah prayers at night, but if not in the month of Ramadan, it's not tarawih, but merely pray night or tahajjud. Prophet nightly routine prayers tahajjud, both within and outside the Ramadan month of Ramadan. In particular at night during Ramadan, he worked on an addition, tarawih prayer done at the beginning of the night coupled with evening prayers', which is exemplified by the Prophet in congregation in the mosque. While praying tahajjud done at the end of the night after waking from sleep, do it more often he is alone in his house, even if there is a history ever done in congregation in the mosque. The most important time to pray or tahajjud night this is the last third of the night or at dawn.
\end{abstract}

Keywords: Prayer, Taraweeh, Tahajud

\begin{abstract}
Abstrak
Shalat Tarawih disyariatkan hanya pada bulan Ramadhan. Di luar dari bulan Ramadhan, tidak disyariatkan untuk melaksanakan shalat Tarawih. Meskipun seseorang yang melaksanakan shalat sunnah pada malah hari, tetapi jika tidak di malam bulan Ramadhan, tidak disebut dengan shalat Tarawih, tetapi itu hanya shalat Malam atau Tahajjud. Nabi selalu rutin shalat malam atau tahajud, baik di bulan Ramadhan maupun di luar bulan Ramadhan. Khususnya di malam hari pada bulan Ramadhan, ia juga melaksanakan shalat selain shalat tarawih, shalat tarawih dilakukan pada awal malam ditambah dengan shalat malam atau Tahajjud, yang selalu dicontohkan oleh Nabi ketika shalat berjamaah di masjid. Sementara shalat tahajud dilakukan pada akhir malam setelah bangun dari tidur, melakukannya lebih sering dia sendirian di rumahnya, bahkan jika ada riwayat dia juga pernah melakukan berjamaah di masjid. Waktu yang paling penting untuk berdoa atau tahajud malam ini adalah sepertiga terakhir malam atau subuh.
\end{abstract}

Kata Kunci: Shalat, Tarawih, Tahajjud

\section{PENDAHULUAN}

Secara bahasa, kata tarawih (تراويح) adalah bentuk jama dari bentuk tunggalnya, yaitu tarwihah (ترويحة) Maknanya secara bahasa adalah istirahat. Namun yang dimaksud adalah duduk dengan jeda waktu agak lama di antara rangkaian rakaat-rakat shalat itu. Secara 
syariah shalat tarawih adalah shalat sunnah yang hanya dilakukan pada malam bulan Ramadhan, dengan dua-dua rakaat, dimana para ulama berbeda pendapat tentang jumlahnya. ${ }^{1}$

Shalat tarawih dikenal sebagai shalat yang dilakukan pada malam bulan Ramadhan. Dahulu Rasulullah SAW pernah melakukannya di masjid bersama dengan beberapa sahabat. Namun pada malam berikutnya, jumlah mereka menjadi bertambah banyak. Semakin bertambah lagi pada malam berikutnya. Dengan itu lantas Rasulullah SAW memutuskan untuk tidak melakukannya di masjid bersama para sahabat. Alasan yang dikemukakan saat itu adalah takut shalat tarawih itu diwajibkan. Karena itu kemudian mereka shalat sendiri-sendiri.

\section{SEJARAH SHALAT TARAWIH}

Shalat Tarawih merupakan Sunnah dikerjakan oleh umat Islam pada Bulan Ramadhan kemudian waktu shalat tarawih dilaksanakan pada waktu setelah Isya dan umumnya dilakukan secara berjamaah di Masjid. Fenomena yang terjadi bahwa ketika itu Rasulullah melakukan Shalat tarawih secara berjamaah.

Dalam 3 kali kesempatan sejarah ini bermula pada waktu Rasulullah masuk Masjid pada malam tanggal 23 Ramadhan tahun keduan Hijriah. kemudian Rasulullah melakukan Shalat, maka dari itu shalat tersebut dinamakan shalat tarawih. Malam berikutnya pada tanggal 25. Rasulullah kembali ke masjid untuk melakukan Shalat, pada saat itu para sahabat bertambah banyak. dan pada tanggal 27 Ramadhan juga melakukan shalat. Kemudian malam-malam selanjutnya para sahabat menuggu untuk shalat Tarawih, dan pada tanggal 29 Ramadhan para sahabat menunggu Nabi ternyata Nabi belum juga hadir. ${ }^{2}$

Pada riwayat yang lain juga disebutkan, dahulu Rasulullah SAW pernah melakukan shalat tarawih di Masjid bersama dengan beberapa sahabat. Namun pada malam berikutnya, jumlah mereka menjadi bertambah banyak. Dan semakin bertambah lagi pada malam berikutnya. Karena itu kemudian Rasulullah SAW memutuskan untuk tidak lagi melakukannya di masjid bersama para sahabat. Alasan yang dikemukakan saat itu adalah takut shalat tarawih itu diwajibkan. Karena itu kemudian mereka shalat sendirisendiri. Dalam sebuah hadist yang diriwayatkan oleh Imam Bukhori sebagai berikut.

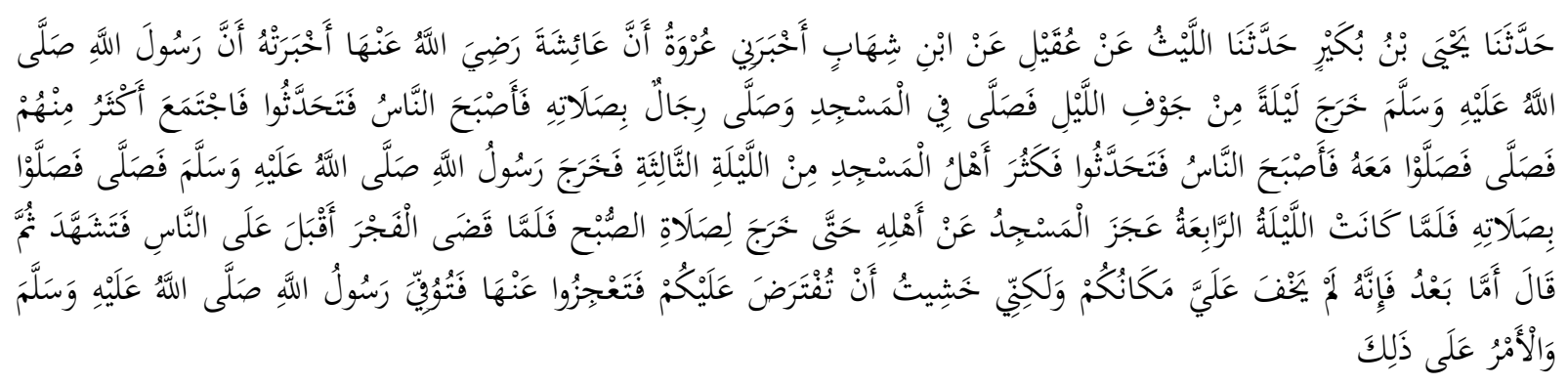

${ }^{1}$ Rahmat Syafe'i, Pedoman Shalat (Semarang: PT Pustaka Rizki Putra, 1950), hlm. 38.

${ }^{2}$ Ahmad Sarawat, Seri Fiqish Kehidupan Pengantar Fiqih, (Jakarta: DU Publishing, 2011), hlm. 41. 
Artinya: “Telah menceritakan kepada kami Yahya bin Bukair telah menceritakan kepada kami Al Laits dari 'Uqail dari Ibnu Syihab telah mengabarkan kepada saya 'Urwah bahwa 'Aisyah radliallahu 'anha mengabarkannya bahwa Rasulullah shallallahu 'alaihi wasallam pada suatu malam keluar kamar di tengah malam untuk melaksanakan shalat di masjid. Maka orang-orang kemudian ikut shalat mengikuti shalat Beliau. Pada waktu paginya orang-orang membicarakan kejadian tersebut sehingga pada malam berikutnya orang-orang yang berkumpul bertambah banyak lalu ikut shalat dengan Beliau. Pada waktu paginya orangorang kembali membicarakan kejadian tersebut. Kemudian pada malam yang ketiga orang-orang yang hadir di masjid semakin bertambah banyak lagi lalu Rasulullah shallallahu 'alaihi wasallam keluar untuk shalat dan mereka ikut shalat bersama Beliau. Kemudian pada malam yang keempat, masjid sudah penuh dengan jama'ah hingga akhirnya Beliau keluar hanya untuk shalat Shubuh. Setelah Beliau selesai shalat Fajar, Beliau menghadap kepada orang banyak kemudian Beliau membaca syahadat lalu bersabda: "Amma ba'du, sesungguhnya aku bukannya tidak tahu keberadaan kalian (semalam). Akan tetapi aku takut nanti menjadi diwajibkan atas kalian sehingga kalian menjadi keberatan karenanya". Kemudian setelah Rasulullah shallallahu 'alaihi wasallam meninggal dunia, tradisi shalat (Tarawih) secara berjamaah terus berlangsung seperti itu.) ${ }^{3}$

\section{DASAR HUKUM SHALAT TARAWIH}

Tradisi menjalankan ibadah shalat tarawih adalah tradisi yang dilandasi dengan dalil-dalil yang Qath'i, baik secara sanad maupun secara dilalah. Shalat tarawih adalah sunnah Rasulullah SAW yang kemudian menjadi tradisi seluruh bangsa muslim di dunia untuk melaksanakannya, meski hukumnya bukan wajib tetapi sunnah.

Dasarnya adalah apa yang dikerjakan oleh Rasulullah SAW:

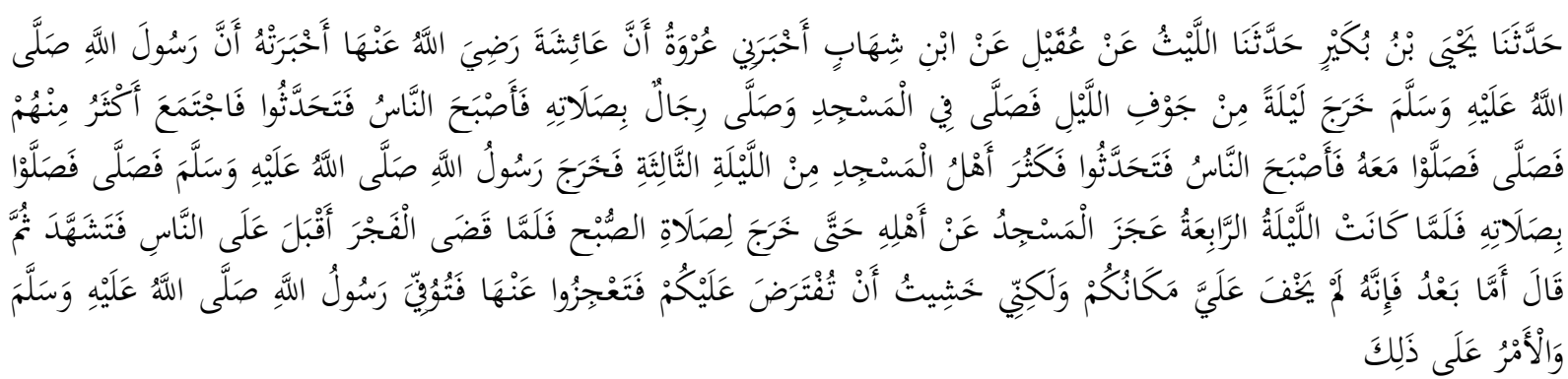

Artinya: Telah menceritakan kepada kami Yahya bin Bukair telah menceritakan kepada kami Al Laits dari 'Uqail dari Ibnu Syihab telah mengabarkan kepada saya 'Urwah bahwa 'Aisyah radliallahu 'anha mengabarkannya bahwa Rasulullah shallallahu 'alaihi wasallam pada suatu malam keluar kamar di tengah malam untuk melaksanakan shalat di masjid. Maka orang-orang kemudian ikut shalat mengikuti shalat Beliau. Pada waktu paginya orang-orang membicarakan kejadian tersebut sehingga pada malam berikutnya orang-orang yang berkumpul bertambah banyak lalu ikut shalat dengan Beliau. Pada waktu paginya orang-orang kembali membicarakan kejadian tersebut. Kemudian pada malam yang ketiga orang-orang 
yang hadir di masjid semakin bertambah banyak lagi lalu Rasulullah shallallahu 'alaihi wasallam keluar untuk shalat dan mereka ikut shalat bersama Beliau. Kemudian pada malam yang keempat, masjid sudah penuh dengan jama'ah hingga akhirnya Beliau keluar hanya untuk shalat Shubuh. Setelah Beliau selesai shalat Fajar, Beliau menghadap kepada orang banyak kemudian Beliau membaca syahadat lalu bersabda: "Amma ba'du, sesungguhnya aku bukannya tidak tahu keberadaan kalian (semalam). Akan tetapi aku takut nanti menjadi diwajibkan atas kalian sehingga kalian menjadi keberatan karenanya". Kemudian setelah Rasulullah shallallahu 'alaihi wasallam meninggal dunia, tradisi shalat Tarawih secara berjamaah terus berlangsung seperti itu. ${ }^{4}$

\section{RAKAAT SHALAT TARAWIH DAN PENDAPAT ULAMA'}

Rakaat tarawih yang dikerjakan Rasulullah adakalanya 8 rakaat dan adakalanya sepuluh rakaat, tidak lebih dari pada itu. Sesudah itu menutup dengan sunnat witir, sehingga berjumlah sebelas rakaat. ${ }^{5}$

Diriwayatkan oleh Al-Jama'ah dari Aisyah RA.:

$$
\text { انه }
$$

Artinya: "Bahwasanya Nabi SAW. tiada mengerjakan shalat malam, baik di ramadlan, maupun dilainnya, lebih dari sebelas raka'at." (H.R. Al Bukhary dan Muslim.

Diriwiyatkan oleh Ibnu Hibban dan Ibnu Khuzaimah dalam Shahih-nya dari Jabir R.A.:

$$
\text { انه صلعم صلى بكم ثماني ركعات والوتر فانتظروه في القابلة فلم يخرج اليهم . }
$$

Artinya: "Bahwasanya Nabi SAW. Mengerjakan shalat dengan mereka ( para sahabat) delapan raka'at dan mengerjakan witir. Kemudian mereka menanti kedatangan rasulullah di malam berikutnya, maka rasulullah tiada keluar masjid"

Diriwiyatkan oleh Abu Ya'la dan Ath Thabrany dari jabir, ujarnya:

“Ubay ibn Ka'ab datang kepada Rasulullah dan berkata : "Ya Rasulullah, saya telah berbuat sesuatu, semalam" ( hal ini terjadi dalam bulan Ramadlan). Nabi bertanya : "Apakah yang telah engkau lakukan itu?" ubay menjawab "ada beberapa orang wanita di rumahku berkata : kami tidak bisa membaca alQuran ( kami tidak banyak menghafal surat-surat Al Qur'an ), maka kami tidak dapat mengerjakan shalat sebagaimana yang engkau kerjakan." Karena itu sayapun bershalatlah dengan mereka, sebanyak delapan raka'aat dan kemudian saya berwitir, "mendengar itu Nabi SAW, tidak mengatakan apaapa. Maka perbuatan Ubay itu menjadi suatu "Sunnatur Ridha'".

Ringkasnya, rakaat yang shalat diperoleh dari Nabi SAW. Hanyalah delapan raka'at. Akan tetapi di masa Umar RA, 'Utsman RA. Dan Ali RA dikerjakan dua puluh raka'at. Jumhur fuquha, baik dari golongan Hanafiyah, Syafiiyah, Hanabilah dan daud menetapkan demikian, yakni dua puluh raka'at. Demikian pulalah pendapat Ats Tsaury, Ibnul Mubarak

${ }^{4}$ Rahmat Syafe'i, Pedoman Shalat,...., hlm. 44.

${ }^{5}$ Ahmad Sarawat, Seri Fiqih Kehidupan Pengantar Fiqih,..., hlm. 43. 
dan Asyafi'iy. Malik berpendapat, bahwa bilangan raka'at, "Qiyamullail" 36 raka'at selain dari witir. ${ }^{6}$

Sebagian ulama' berpadapat, bahwa yang disunnatkan hanyalah sebelas rakaat beserta witir. Al Kamal Ibnul Humam menyebutkan dalil yang diperoleh dalam masalah ini menghendaki atau menetapkan bahwa yang sunnah dari yang dua puluh raka'at beserta witir, kemudian Nabi SAW, meninggalkannya, karena takut akan difardukan. ${ }^{7}$

Berkata Al-Adzra'iy dalam Al-Mutawassith:

"Riwayat yang meriwayatkan bahwa Rasulullah SAW, mengerjakan shalat di malam itu dua puluh rakaat adalah munkar"

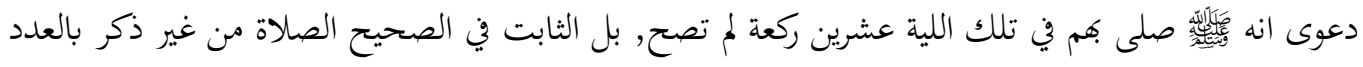

Artinya: "Mengatakan bahwa rasulullah Saw. Bershalat dengan para sahabat di malam itu dua puluh raka'at tiada shah hanya yang ada di dalam kitab shahih, ialah Rasulullah SAW. Bershalat dengan tidak disebut bilangan raka'atnya"

Ringkasnya, tidak ada sebuah hadist yang marfu' untuk menetapkan bahwa bilangan raka'at tarawih itu dua puluh. Demikian pula halnya hadist yang menerangkan, bahwa rasulullah SAW, bershalat di dalam masjid delapan rakaat, kemudian beliau mengerjakan dua belas lagi di rumahnya, adalah dlaif dan lemah.

\section{PERBEDAAN ANTARA SHALAT TARAWIH DAN TAHAJJUD}

Meski sama-sama tercakup dalam agenda qiyamullail, namun umumnya para ulama membedakan antara shalat tarawih dengan tahajjud. Setidaknya ada delapan perbedaan yang bisa kita catat dalam kesempatan ini. Di antara perbedaan-perbedaan itu antara lain:8

1. Masa pensyariatan tarawih

Tarawih belum disyariatkan ketika Rasulullah SAW masih di Mekkah, maka selama di masa Mekkah tidak dikenal shalat tarawih, karena baru nanti ketika di Madinah setelah hijrah Rasulullah SAW melaksanakannya.Berbeda dengan shalat tahajjud yang disyariatkan sejak awal mula masa kenabian.

Ada yang mengatakan bahwa wahyu kedua yang turun sudah memerintahkan bangun malam dalam arti shalat tahajjud. Intinya, shalat tahajjud sudah dikenal dan disyariatkan sejak masih di masa Mekkah.

Hingga akhir masa kehidupan Nabi SAW, beliau masih terus melakukan shalat tahajjud. Adapun shalat tarawih dengan alasan takut diwajibkan, beliau SAW dan para sahabat tidak lagi melakukannya hingga wafat. Dari sisi pensyariatannya saja, tarawih dan tahajjud memang sudah berbeda. Karena itu janganlah rancu dalam memahami keduanya.

${ }^{6}$ Ahmad Sarawat, Seri Fiqih Kehidupan Pengantar Fiqih,..., hlm. 47.

${ }^{7}$ Ramli Abdul Wahid, Kuliah Agama Ilmiah Populer, (Bandung, Citapustaka Media, 2005), hlm. 102.

${ }^{8}$ Ahmad Sarawat, Seri Fiqih Kehidupan Pengantar Fiqih,..., hlm. 49. 
2. Tarawih Nabi SAW hanya tiga kali.

Seperti disinggung di atas, bila ditelurusi hadits-hadits yang shahih, ternyata shalat tarawih di masa Nabi SAW dilakukan hanya tiga kali saja. Shalat itu dilakukan secara berjamaah dan dilakukan di dalam masjid nabawi. Semakin hari semakin ramai para sahabat yang mengikutinya, hingga kemudian beliau SAW menghentikannya. Dengan itu para sahabat pun otomatis juga meninggalkannya. Alasannya karena beliau khawatir bila tarawih diwajibkan dan akan memberatkan.

Tidak ada keterangan yang valid apakah beliau SAW mengerjakannya sendirian di rumah. Yang jelas ketika meninggalkannya, Rasulullah SAW menegaskan alasannya, yaitu karena takut tarawih itu diwajibkan. Adapun shalat tahajjud dilakukan oleh Rasulullah SAW setiap malam, tanpa pernah dihentikan lantaran takut diwajibkan. Karena itu sepanjang hidupnya pada tiap malam beliau SAW selalu melakukan shalat tahajjud. Tidak peduli apakah di dalam bulan Ramadhan atau di luar bulan Ramadhan, karena tahajjud khusus buat beliau SAW hukumnya wajib.

3. Tarawih hanya di bulan Ramadhan.

Para ulama umumnya sepakat bahwa shalat Tarawih itu bukan shalat tahajjud. Hal utama yang membedakan tarawih dengan tahajjud adalah bahwa tarawih ini hanya disyariatkan di bulan Ramadhan saja.

Tidak ada shalat tarawih yang dikerjakan di luar bulan Ramadhan. Di luar bulan Ramadhan, kalau ada shalat yang disunnahkan, hanya shalat tahajjud dan shalat witir. Tahajjud dilakukan oleh Rasulullah SAW setelah beliau tidur malam, sedangkan shalat witir merupakan penutupnya. Namun ada juga keterangan bahwa shalat witir itu bisa dikerjakan sebelum tidur. Namun namannya tetap shalat witir dan bukan tarawih.

4. Tarawih berjamaah di masjid

Perbedaan penting antara tarawih dan tahajjud adalah bahwa selama tiga kali Rasulullah SAW dan para sahabat melakukannya, semua dilakukan dengan berjamaah yang amat banyak, bahkan hingga memenuhi Masjid Nabawi kala itu. Bahkan salah satu alasan kenapa shalat tarawih saat itu dihentikan juga salah satunya karena jamaahnya semakin banyak. Sehingga Rasulullah SAW khawatir bila hal itu dibiarkan terus menerus, akhirnya akan diwajibkan oleh Allah SWT. Sedangkan shalat tahajjud, meski hukumnya boleh berjamaah, tetapi dalam kenyataannya Rasulullah SAW lebih sering melakukannya sendirian, tidak mengajak orang-orang untuk ikut di belakang beliau. Kadang beliau mengerjakannya di dalam rumah (kamar Aisyah), kadang beliau lakukan di dalam masjid.

Kalau pun ada sahabat yang ikut jadi makmum, paling-paling satu dua orang saja. Tidak ada catatan bahwa shalat tahajjud yang beliau SAW lakukan diikuti orang satu masjid. Oleh karena itulah kebanyakan ulama lebih menganjurkan shalat tahajjud dikerjakan sendirian. 
5. Tarawih sebelum tidur.

Shalat tarawih yang dilakukan oleh Rasulullah SAW dan para sahabat yang hanya tiga kali itu ternyata dilakukan sesudah shalat isya' dan sebelum tidur malam. Mirip dengan yang semua orang lakukan di masa sekarang ini. Sedangkan shalat tahajjud dilakukan oleh Rasulullah SAW di akhir malam, setelah beliau SAW selesai beristirahat tidur malam.

Secara bahasa, kata tahajjud (هُجد) berasal dari kata hujud (هود). Kata tahajjud punya dua arti sekaligus yang berlawanan, begadang dan tidur. Jadi bisa diterjemahkan menjadi begadang, tapi kadang bisa juga diterjemahkan menjadi tidur. Al-Azhari dalam Lisanul Arab menyatakan bahwa bila kita menyebut Al-Hajid (الهاجد) artinya adalah orang yang tidur. Kata hajada (هجد) bermakna tidur di malam hari (نامبالليل).9

Sedangkan kalau disebut Al-Mutahajjid (المتهجد) artinya adalah orang yang bangun pada malam hari untuk ibadah. Seolah-olah mutahajjid ini adalah orang yang membuang hujud (tidur) dari dirinya. Sedangkan secara istilah syariat, di dalam kitab Nihayatul Muhtjd jilid 2 hal. 127 disebutkan bahwa tahajjud adalah :

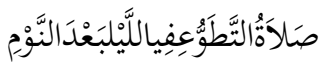

Artinya: Shalat tathawwu' pada malam hari setelah bangun dari tidur.

Hal ini dikuatkan dengan hadits dari Al-Hajjaj bin Amr:

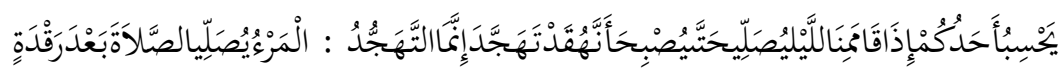

Artinya: "Ada seorang diantara kalian yang mengira bila seseorang shalat di malam hari hingga shubuh, dia dikatakan sudah bertahajjud. Padahal tahajjud itu adalah seseorang melakukan shalat setelah bangun dari tidur."

6. Rakaat tarawih ikhtilaf

Bicara jumlah rakaat tahajjud, kita punya banyak hadits yang menyebutkan bahwa beliau SAW mengerjakannya dengan 11 atau 13 rakaat.

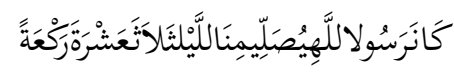

Artinya: Adalah Rasulullah SAW shalat malam dengan 13 rakaat (HR. Muslim)

Namun ada juga hadits yang menyebutkan bahwa beliau SAW shalat malam tidak lebih dari 11 rakaat, sebagaimana hadits Aisyah radhiyallahuanha berikut ini:

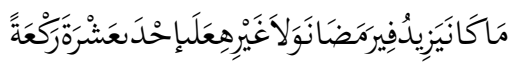

Artinya: Beliau SAW (shalat malam) tidak pernah lebih dari 11 rakaat, baik di dalam bulan Ramadhan atau di luar bulan Ramadhan (HR. Bukhari)

Ternyata memang tidak ditemukan haditsnya. Dengan demikian berapa jumlah rakaatnya, tidak pernah disebutkan dalam hadits secara tegas. Bila ada menyatakan

${ }^{9}$ Ibrahim Husein, Kumpulan Fatwa Majelis Ulama Indonesia, (Jakarta, Pustaka Panji Mas, 1984), hlm 121134. 
beliau mengerjakan 11 atau 20 rakaat, tentu bukan merupakan fakta dari nash hadits, melainkan sekedar tafsir dan asumsi.

Memang ada segelintir orang yang bilang bahwa beliau tarawih 11 rakaat berdasarkan hadits Aisyah yang shahih. Haditsnya memang shahih, tetapi para ulama umumnya sepakat bahwa hadits itu bukan terkait dengan shalat tarawih, melainkan shalat tahajjud itu sendiri.

Jika untuk shalat tahajjud, umumnya para ulama sepakat bahwa Rasulullah mengerjakannya 11 rakaat. Tetapi untuk tarawih, tidak ada satu pun dalil tentang jumlahnya di masa Nabi SAW. Data yang paling valid tentang jumlah rakaat tarawih adalah tarawih yang dilakukan seluruh sahabat sepeninggal Rasulullah SAW di masa kepemimpinan Umar bin Al-Khattab radhiyallahuanhu, tepatnya tahun kedua sejak beliau menjadi khalifah.

Seluruh shahat telah berijma' untuk mengerjakan tarawih sebanyak 20 rakaat, tidak ada satupun yang menolaknya. Asumsinya, kalau seluruh sahabat mengerjakan 20 rakaat, pastilah mereka tidak ngasal dan bukan ngarang. Logikanya, pastilah mereka melakukannya persis seperti yang dahulu mereka lakukan di masa Nabi SAW, yaitu sebanyak 20 rakaat.

7. Hukum shalat tarawih.

Meski pernah dihentikan pengerjaannya di masa Nabi SAW, namun para ulama sepakat bahwa penghentian itu bukan berarti pencabutan atas pensyariatannya. Penghentian itu semata karena alasan takut diwajibkan, sehingga ketika beliau SAW wafat, maka kekhawatiran itu tidak lagi beralasan. Sebab tidak ada pensyariatan apapun sepeniggal beliau SAW. Dengan itu para sahabat menjalankan shalat tarawih ini dengan status hukum sunnah, dan sebagian lagi memberi status sunnah muakkadad. Berbeda dengan tahajjud, dimana banyak ulama mengatakan bahwa hukumnya wajib buat Rasulullah SAW dan sunnah buat ummatnya.

8. Tarawih banyak istirahatnya

Perbedaan yang juga dapat dicatat bahwa shalat tarawih ini banyak istirahatnya, sebagaimana nama yang disematkan kepadanya. Duduk istirahat di sela-sela rakaat tarawih itu menjadi amat mutlak diperlukan. Karena umumnya jumlah rakaatnya banyak dan bacaannya cukup panjang.

Tidak mungkin semua itu dilakukan dengan cara berdiri terus-terusan tanpa jeda istirahat. Apalagi yang ikut shalat ini cukup banyak jumlahnya. Lain halnya tahajjud yang umumnya Nabi SAW melakukannya sendirian. Banyak riwayat yang menyebutkan bahwa beliau SAW salam sampai bengkak kakinya, karena memakan waktu sangat lama. Tidak ada riwayat yang menyebutkan bahwa beliau bersitirahat di sela-sela rakaat tahajjud. 


\section{PENUTUP}

Dari uraian di atas dapat diambil suatu intisari bahwa shalat tarawih merupakan bentuk ibadah yang hanya dilaksanakan pada saat bulan Ramadhan dan hukumnya sudah Qot'i ( Sunnah). Shalat tarawih boleh 8 rakaat, 4-4 rakaat dan diakhiri 3 rakaat witir, atau 10 rakaat, 2-2 rakaat dan satu witir. Demikianlah di masa nabi dan abu bakar. Kemudian di masa Umar Ibn Khattab dijadikan 20 rakaat. Al Baihaqy telah mengumpul semua riwayatriwayat itu.

Diriwiyatkan itu nyatalah bahwa para sahabat mula-mula mengerjakan 8 rakaat kemudian mereka mengerjakan 20 dengan witir 3 rakaat. Diterangkan oleh Asy Syaukani bahwa hadist-hadist yang diperoleh dalam bab ini hanya menunjukkan kepada adanya qiyam Ramadlan, berjamaah atau bersendiri-sendiri. Karena itu menetapkan shalat yang disebut tarawih dengan dengan bilangan tertentu dan mengkhususkannya dengan bacaan tertentu tidak ada sunnahnya dari Nabi SAW. 
FITRAH Vol.01 No. 2 Juli-Desember 2015

\section{DAFTAR PUSTAKA}

Ahmad Sarawat, Seri Fiqih Kehidupan Pengantar Fiqih, DU Publishing, Jakarta 2011.

Rahmat Syafe'i, Pedoman Shalat, PT Pustaka Rizki Putra, Semarang, 1950.

Ramli Abdul Wahid, Kuliah Agama Ilmiah Populer, Citapustaka Media, Bandung, 2005.

Ibrahim Husein, Kumpulan Fatwa Majelis Ulama Indonesia, Pustaka Panji Mas, Jakarta, 1984. 